Алфа универзитет, Академија уметности, Катедра продукције у уметности и медијима, Београд

DOI 10.5937/kultura1650224P УДК 7.061

\title{
ФАЛСИФИКАТИИ
}

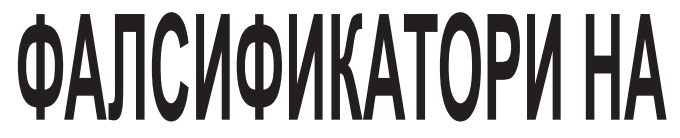
TPXWUTY RERA ЛИКОВНИХУМЁНОСТИ

\begin{abstract}
Сажетак: За многе фалсификате се годинама, па и вековима, веровало да су оригинали. С напретком науке и технологије, постало је могуће урадити велики број анализа уметничких дела у чију се оригиналност посумьа, па би се очекивало да се оне раде рутински. Ипак, то није случај. Испитивања могу да буду скупа, дуго да трају, а нека од юих и неповратно оштећују дело које се испитује. Тако смо дошли у ситуацију да и најпрестижнији музеји широм света у својим колекиијама имају кривотворена дела, као и да их повремено нуде најпознатије аукиијске куће по цени оригинала. Када знамо да је вредност појединих уметничких дела достигла милионске износе, јасно је да је њихово фалсификовање постало врло уносан бизнис. Пошто је аутентичност дела које је скоро настало најтеже утврдити, јер су коришћени доступни материјали, може се очекивати да ће у блиској будућности тржиште дела ликовних уметности бити преплављено фалсификованим радовима савремених уметника.
\end{abstract}

Кључне речи: фалсификати, фалсификатори, тржсите дела ликовних уметности, музејске збирке, колекционари

Не сматрамо све копије дела ликовних уметности фалсификатима. И данас се многи млади уметници обучавају копирајући дела великих мајстора, али се не потписују као они и 


\section{ДЕЈАНА ПРњАТ}

не покушавају да их продају по цени оригинала. Суштинска одлика фалсификата је намера да се неко превари, најчешће ради стицања материјалне користи. Шта се дешава у ситуацији „кад уметник сам преправља своје дело?,” питање је које отвара Гордић Петковић говорећи о роману Саше Обрадовића „Врт љубави”. Отвара се и питање шта када сликар сам плагира своје дело? Јер јасно је да постоји могућност да сликар несвесно пренесе мотиве неке слике коју је некада видео, чиме постаје плагијатор, или чак неког свог дела, чиме постаје аутоплагијатор, али се не може бити несвесно фалсификатор, јер не постоји моугћност да се неко несвесно потпише као Рембрант, објашњава Дантон. ${ }^{2}$ И копије и фалсификати могу бити јавно изложени, али са јасном назнаком о чему се ради, као што су у Галерији фресака Народног музеја у Београду изложене копије средњовековних фресака византијског стила или у Музеју фалсификата у Бечу. Уколико то није случај, настаје проблем.

Прве копије скулптура античке Грчке настале су када је „римски војсковођа Мумије (...) после пада Коринта (146. године пре н. е.) донео из побеђеног града грчке статуе за своје виле и вртове, па је у Риму тада настала потражња за таквим статуама. Куповале су се и продавале мермерне копије грчких оригинала..., а римски богаташи и властодршци (Сула, Лукул, Крас, Помпеј, Цезар, Брут, Антоније) постају главни колекционари грчке пластике и слика." Када се Мумије договарао са превозницима који су требали да пренесу грчке артефакте у Рим рекао им је да ће, уколико их оштете, морати да надокнаде вредност другом врстом робе. ${ }^{4}$ Овај његов став се тумачи као израз његове незаинтересованости за скулптуре и незнање, али да је тако не би их ни превозио у Рим да украси своја имања. Могуће је да је на тај начин преговарао с превозницима да би они схватили да морају да буду пажљиви са скулптурама које превозе.

Дуго година највећи наручиоци уметничких дела у Западној Европи били су представници световне и религијске власти. Са појавом богатих грађана рађа се и уметничко тржиште. Када говоримо о ликовним уметностима, појављују се колекционари, дилери, а касније и аукцијске куће које и данас „диктирају цене целокупном светском тржишту. Цене

1 Gordić Petković, V. (2009) Formatiranje, Beograd: Službeni glasnik, str. 97

2 Dutton, D. Forgery and Plagiarism, 24. 03. 2016. http://www.denisdutton. com/forgery_and_plagiarism.htm

3 Indjić, T. (1986) Tržište dela likovnih umetnosti, Beograd: Zavod za proučavanje kulturnog razvitka, str. 14

4 http://www.britannica.com/biography/Lucius-Mummius (03. 03. 2016.) 
се мењају, али за квалитетне слике старих мајстора оне су у сталном порасту." ним делима, на тржишту се појавио и већи број фалсификата, обично као „пронађена” давно изгубљена дела или су се „откривала нова.” Да би кривотворена дела могла да се продају као оригинали, фалсификовали су се и документи који би требало да потврде аутентичност дела.

Научним одељењима у великим музејима данас је на располагању велики број могућности када се ради о анализи артефаката. „Ултравиолетна илуминација може брзо да открије додатке или промене на слици јер различити слојеви боје и лака светле различитим нијансама. Стари мермер добија патину која светли зеленкастожуто, док је нови мермер или стари комад мермера недавно извајан, светлољубичаст. Инфрацрвено светло, фотографисано кроз одговарајући филтер лежи исиспод површинског слоја. Овако се може открити старија слика на истом платну (што само по себи не указује на фалсификат, бубудући да су многи уметници сликали преко сопствених слика) или потпис који је скривени замењен неким вреднијим. Радијација рендгенских зрака може да се употреби на исти начин...“6, а ту су и хемијске анализе укључујући спектрографију, термолуминисценција, и датиранје радиокарбоном. И када изгледа да је технологија довољно напредовала да се фалсификати више не могу сакрити, треба се сетити да се и фалсификатори образују, да и они користе напредније технике.

Тако се поново враћамо на значај процене коју раде искусни кустоси. Међутим, превише ослањања на људски фактор има и својих мана, јер су људи понекад спремни да свесно дају лажне процене. Понекада се посумња да директори галерија знају да продају фалсификате, ${ }^{7}$ да угледни стручњаци дају лажне потрвде о аутентичности дела које процењују за материјалну надокнаду, да се за новчану надокнаду добијају лажне потврде да су артефакти дуго били у власништву угледних породица и слично. Најпознатији случај код нас везан за процену радова домаћих сликара је случај са бившим кустосем Народног музеја у Београду Николом Кусовцем, који је био оптужен да је у кратком року лажно проценио за шест фалсификата да су оригинали, у договору са

5 Indjić, T. nav. delo, str. 15.

6 Ins, B. (2008) Prevare i falsifikati, Beograd: Mladinska knjiga, str. 62.

7 Više u: Smith, J. Art-Forgery Trial Set to Begin, 22. 01. 2016, 23.02. 2016. http://www.wsj.com/articles/art-forgery-trial-set-to-begin-1453484615 


\section{ДЕЈАНА ПРњАТ}

дилером који је онда те фалсификате продавао, али је 2013. године ослобођен свих оптужби. ${ }^{8}$

Неке процене делују као политичка одлука. Јапанска компанија купила је за скоро 25 милиона фунти Ван Гогове „изненада откривене” сунцокрете. Пошто је јавила сумња да је у питању фалсификат, јер се зна само за његових шест слика сунцокрета у вази, они су се обратили Музеју Ван Гога у Амстердаму за процену, а нешто раније су им донирали велики износ. Стручњаци из Холандије су већали и званично прогласили свих седам оригиналима. Верује се да је Ван Гог најчешће фалсификован модерни ликовни уметник, као и да Леонардова Mona Lisa најкопиранија слика свих времена. Неке од копија старе су готово као и оригинал, па није сигурно ни да ли је она из Лувра „права”.

\section{Фалсификати}

Све је већи број људи који имају могућност и жељу да плате високу цену за добро очувану скулптуру из античког раздобља. Како је број оваквих скулптура врло ограничен и све ређе у добром стању, отвара се простор у коме фалсификатори и дилери уметничких предмета виде своју шансу. Као и у сваком другом бизнису, и овде се улаже да би се извукла корист. Дилер Кристофа Леона (Christoph Leon) открива да је за израду добре копије бронзане скулптуре у природној величини потребно унапред уложити око милион евра. ${ }^{10}$ У питању је врло уносан посао, јер се на тржишту постиже многострука добит, па постоје и радионице фалсификата, од којих су најразрађеније оне у Италији и Шпанији, додаје Шулц.

Малком Гладвел (Malcolm Gladwell) своју књигу Блинк започиње случајем Куроса, античке скултпуре нагог младића који стоји, који је пре више од три деценије продат Музеју $Ц$. Пол Гети (J. Paul Getti Museum) у Калифорнији. ${ }^{11}$ За статуу израђену од мермера, високу преко два метра, музеј је платио 10 милиона долара. Уз скулптуру су добили и потврда о пореклу, која је сведочила да се скулптура налазила у породичној колекцији угледног Швајцарца од 1930. године.

8 Никола Кусовац ослобођен свих сумњи, 10. 03. 2013, 30. 03. 2016. http:// www.politika.rs/scc/clanak/251304/Nikola-Kusovac-osloboden-svih-sumnji

9 Dutton, D. Art Hoaxes, 22. 03. 2016. http://denisdutton.com/art_hoaxes.htm

10 Schulz, M. False Gods: „Ancient“ Forgeries Fool Art Markets, January 23, 2008, 28. 03. 2016, http://www.spiegel.de/international/europe/false-godsancient-forgeries-fool-art-markets-a-529532-2.html

11 Gladwell, M. (2007) Blink, NY, Boston, London: Back Bay Books, pp. 3-8. 
Пре куповине, стручњаци из музеја су направили анализу мермера и утврдили да је заиста стар око 2500 година и да потиче са грчког острва Тасоса. Скулптура је била прекривена калцијум карбонатом, што је нормална појава када мермер дуго стоји у земљи и куповина је обављена. Проблем се појавио када су сви историчари уметности који су видели Kуроса, имали задршку када је у питању аутентичност ове скулптуре. Нико није умео да објасни у чему је проблем, али је свима деловало да нешто са скулптуром није у реду.

Да би се ослободили сумњи, музеј је организовао симпозијум кустоса у Атини, који је имао за тему само ову скулптуру. Било је пуно замерки, али не и потпуна сигурност да је у питању фалсификат. Музеј се окренуо и проучавању потврде о пореклу и за њу је доказано да је кривотворена. Међутим, ово откриће указује само да артефакт нема легално порекло, па још увек постоји могућност да је скулптура оригинална, али да је, на пример, илегално набављена. Данас је ова скулптура изложена у Гетију, уз напомену да артефакт датира из „око 530. године пре нове ере или је савремен фалсификат." 12

Гети није усамљен пример музеја који поседује сумњиве артефакте. Заправо, готово да нема значајнијег музеја у свету који их немају у својој колекцији. У Метрополитену у Њујорку налазе се фалсификати античког бронзаног коња ${ }^{13}$ и староегипатске мачке за коју се веровало да је била посуда за мумифицирану мачку. ${ }^{14}$ Национална галерија у Лондону je 2010. године направила изложбу слика из своје колекциje које су биле погрешно процењене, било да су у питању фалсификати, дела чији се идентитет није одмах открио или дела која су стручњаци свога вемена погрешно приписивали неком аутору. На изложби су се могле видети слике Ботичелија, Дирера, Рафаела, Рембранта. ${ }^{15}$ Ово је и одличан пример реаговања музеја у кризним ситуацијама, који је успео да ублажи проблем фалсификата које поседује, правећи изложбу са свим погрешно процењеним артефактима.

12 The J. Paul Getty Museum, 12.03.2016., http://www.getty.edu/art/collection/ objects/10930/unknown-maker-kouros-greek-about-530-bc-or-modern-forgery/

13 Noble, J.V., (1968) The Forgery of Our Greek Bronze Horse, The Metropolitan Museum of Art Bulletin, February, Ithaka: Jstor p. 256

14 McGill, D.C., Met says its popular cat is probably fake, 30. 04. 1987, 16. 03. 2016., http://www.nytimes.com/1987/04/30/arts/met-says-its-popular-cat-isprobably-fake.html?pagewanted=all

15 Close Examination: Fakes, Mistakes \& Discoveries, 20.03.2016 https:// www.nationalgallery.org.uk/whats-on/exhibitions/close-examination-fakesmistakes-and-discoveries 


\section{ДЕЈАНА ПРњАТ}

Ни Британски музеј није поштеђен фалсификата. Вероватно најинтересантнији је пример лажног етрурског саркофага, који је музеј својевремено купио од италијанског дилера. Годинама су га у музеју склапали, да би га на крају поносно изложили. Да се брат проналазача саркофага није огласио много година касније, тврдећи да га је он направио, вероватно још дуго година овај артефакт не би био додатно анализиран. Чим су га пажљивије погледали, било је јасно да није оригинал, али никоме није било јасно како је могуће да то нису одмах приметили, када су женски ликови са њега носили рубље попут оног које се носило у 19. веку. ${ }^{16}$ Поред експоната пише да се данас верује да је у питању фалсификат, али ће се теже исправити то што су генерације училе о етрурској уметности гледајући овај саркофаг.

Пре неколико година и Немачку је потресао скандал с фалсификатима. Унуке успешног бизнисмена продавале су фалсификате у земљи и иностранству, тврдећи да су их наследиле од богатог деде и зарадиле 16 милиона евра. ${ }^{17}$

Од наших сликара најчешће су фалсификована дела Петра Лубарде, Петра Коњовића, Пеђе Милосављевића, Дада Ђурића, Николе Граовца, а историчар уметности Јован Деспотовић процењује да је тек свака десета слика Миће Поповића оригинал. ${ }^{18}$

\section{Фалсификатори}

Да би један фалсификатор био успешан потребно је да има одличну технику, али и пуно знања о стваралаштву уметника кога намерава да имитира. Неки су се годинама припремали да би њихова копија била беспрекорна, користили дрво или платно које потичу из времена када је уметник кога кривотворе стварао, користе само пигменте који су се користили у то време, док су други давали себи одушка додајући на слику понеки детаљ, као свој лични печат. Ерик Хеборн (Eric Hebborn) je, на пример, сматрао да би свака слика постајала привлачнија, уколико се у први план стави мачка, ${ }^{19}$ па је то

16 The British Museum 24.03.2016, http://www.britishmuseum.org/research/ collection_online/collection_object_details.aspx?objectId=444393\&par$\mathrm{tId}=1$

17 Stafford, N. Analytical techniques employed in art forgery case, 07.09.2011, 28.03.2016.,http://www.rsc.org/chemistryworld/News/2011/September/07091101.asp

18 Ђорђевић, М. У мрачном свету фалсификата, 19. 03. 2013, 20. 03. 2016. http://www.politika.rs/scc/clanak/252262/U-mracnom-svetu-falsifikata

19 Dutton, D., The Art Instinct, 22. 03. 2016. https://books.google.rs/books?id=jqb6WrXS68kC\&pg=PA180\&lpg=PA180\&dq=Eric + Hebborn + painting + cat $\&$ source $=$ bl\&ots $=$ Og 6 AnrQPD\&sig $=$ vaPOf3P7 $18 \mathrm{CFcLr} 5 \mathrm{uC}$ - 
повремено и радио. Написао је више књига о себи и свом занату, од којих су неке имале и више издања и објављене су од стране престижних издавача као што је Мекмилан. У својим књигама он је навео да је фалсификовао око хиљаду слика мајстора попут Рубенса, Ван Дајка и Бројгела, мада се за неке од њих и данас верује да су оригинали. Најпознатија књига му је Приручник за фалсификаторе уметничких дела, чија се цена у овом тренутку на Амазону креће од 180 до 350 америчких долара. ${ }^{20}$ У приручнику су детаљно објашњени поступци који ће учинити да подлога изгледа старо, које пигменте кад треба користити и слично, а очигледно је да је ту материју одлично познавао, када знамо да су његове слике прошле строгу контролу стручњака најпознатијих музеја, аукцијских кућа и приватних колекционара. О њему је и Би-Би-Си направио документарац Портрет врхунског фалсификатора (Portrait of a Master Forger). ${ }^{21}$

И Том Китинг (Tom Keating) је често додавао по неки детаљ приликом кривотворења великих мајстора, и то обично савремен. Он као да није могао да дочека да се похвали својом вештином, па када су пронашли неке фалсификате, сам се пријавио да су његови. Тврдио је да их је још доста урадио, али да не жели да каже које су слике у питању. И он је, као и Хеборн, написао књигу о кривотворењу. ${ }^{22}$

Марк Лендис (Mark Landis) се разликовао од свих осталих, јер не само да није много обраћао пажњу на копије које је правио, већ их никада није ни наплаћивао. Као млад је доживео нервни слом, па му је као терапија препоручено цртање. Тако је откривен његов таленат. У чланку „Амерички најдарежљивији уметник-преварант" Лендис је испричао да, за разлику од осталих фалсификатора, он никада није имао стрпљења да дуго ради на неком делу, већ да би отишао у неку од радњи са јефтином робом попут Волмарта или Вулворта, купио материјал и за сат до два завршио слику. Као разлог својих поступака, навео је потребу да задиви своју мајку, као и да га је увек импресионирало када би неки богати колекционар поклонио скупоцену слику неком

tOZN1AiZ8\&hl=en\&sa $=X \&$ redir_esc $=y \# v=$ onepage $\& q=$ Eric $\% 20 H e b-$ born $\% 20$ painting $\% 20$ cat $\& \mathrm{f}=$ false

$20 \mathrm{http}: / /$ www.amazon.com/The-Forgers-Handbook-Eric-Hebborn/ dp/0879517670 (31.03.2016.)

21 Eric Hebborn: From Restorer to Forger, 31. 03. 2016., http://www.intenttodeceive.org/forger-profiles/eric-hebborn/

22 Keating, T., Fake's Prograss, 13. 03. 2016., http://www.amazon.com/FakesProgress-Tom-Keating/dp/0091294207/ref=sr_1_2?s=books\&ie=UTF8\&qi$\mathrm{d}=1460552373 \& \mathrm{sr}=1-2 \&$ keywords $=$ tom + keating + book 


\section{ДЕЈАНА ПРњАТ}

музеју. ${ }^{23}$ Да би задобио поверење музеја, он би се прерушавао у свештеника и измишљао разне приче да би објаснио због чега жели да им поклони „вредну” слику. И поред дијагностификованих менталних поремећаја, успевао је више деценија да „донира” своје радове као радове значајних сликара великом броју америчких музеја. ${ }^{24}$ Пошто није узимао новац за своје слике, никада није ни био осуђен. О њему је 2014. године снимљен документарац Уметност и занат (Art and Craft) у режији Сема Калмана (Sam Cullman), Џeнифер Граусман (Jennifer Grausman) и Марка Бејкера (Mark Becker).

Вероватно најпознатији фалсификатор ликовних дела је холанђанин Хан Ван Мегерен (Han van Meegeren). Историчари уметности су веровали да су нека Вермерова дела изгубљена, и он је одлучио да их пронађе. „Године 1937, Ван Мегерен запањио је уметничке кругове „открићем” новог Вермера, Христови ученици у Емаусу... Слика је продата фондацији Бојман sa 550.000 флорина, од којих је Ван Мегерен добио две трећине." 25 За његове кривотворине се вероватно не би ни сазнало да након Другог светског рата није био ухапшен због продаје националног блага окупатору. Он je, наиме, продао једног свог Вермера Герингу ${ }^{26}$ по високој цени. Пошто су у питању биле озбиљне оптужбе, био је принуђен да објасни о чему се ради, чак и да нацрта једну као доказ да је заиста способан да то и уради. Он се правдао да је почео да фалсификује да би надмудрио арогантног ликовног критичара др Абрахама Бредијуса (Abraham Bredius), који га није признавао. И то му је пошло за руком. За његовог првог Вермера Бредијус је изјавио да је у питању вероватно најбоље Вермерово дело. ${ }^{27}$ Мегерен је осуђен на затвор и убрзо затим умро, али је током суђења постао херој jep је успео да превари Геринга". Од свих фалсификатора о којима говоримо, он је најтемељније приступао свом раду. На неким сликама је радио годинама. Водио је рачуна о сваком детаљу - подлози коју је користио, употребљавао је

23 Caffrey, J., America's most generous con artist, 31. 03. 2015, 13. 03. 2016., http://www.bbc.com/news/magazine-31818367

24 Mark Landis: Mysterious Donor, 30. 03. 2016., http://www.intenttodeceive. org/forger-profiles/mark-landis/

25 Ins, B. (2008) Prevare i falsifikati, Beograd: Mladinska knjiga, str. 71.

26 Геринг је током рата на разне начине прикупљао вредне артефакте који су пописани у Каталогу Геринг (Jean-Marc Dreyfus, Le catalogue Goering, Flammarion 2015) који је објављен прошле године на 608 страна и у коме се налази списак од 1375 ремекдела.

27 Dutton, D. Forgery and Plagiarism, 24. 03. 2016. http://www.denisdutton. com/forgery_and_plagiarism.htm 
само пигменте који су постојали у периоду када су слике коje је желео да фалсификује настале и слично.

Волфганг Белтрачи (Wolfgang Beltracchi) је фалсификовао радове мање познатих европских сликара који нису пуно изучавани, а његова супруга је тврдила да их је наследила од богатог деде. Белтрачи се на овај начин обогатио и прославио. Објавио је књигу Аутопортрет у којој наводи и оне фалсифкате за које никада није био оптужен, често гостује у медијима, а 2013. године о њему је снимљен и филм „Белтрачи - уметност фалсификовања” (Beltracchi - die kunst der falschung).

Џон Дру (John Drewe), фалсификатор докумената, купио је копију слике старог мајстора од сликара Џона Мајата (John Myatt), а затим је продао Кристију као оригинал за 25.000 фунти. Након тога, два фалсификатора су се удружила и направила хаос на тржишту уметничких дела у Лондону. Мајат је фалсификовао још око 200 слика старих мајстора, док је Дру успео да уђе у најпознатије лондонске галерије, чије архиве служе као референце, убацио фотографије Мајатових копија заједно са лажним документима о пореклу тих слика, које је сам направио, тако да вероватно никада више нећемо знати за неке слике да ли су оригинали. „Као што рече шеф одељења за модерну уметност у Сотбију Мелани Клор 'Одете у архив Тејт галерије, и прегледате књиге најчувенијих лондонских галерија из педесетих година, и пронађете слику на црно-белој фотографији. Немогуће је бити савеснији од тога", ${ }^{28}$

\section{Закључак}

Сматра се да је основни мотив фалсификатора брзо богаћење и да је „свет уметности (...) подједнако као и друге области људских активности заражен похлепом и амбицијом". ${ }^{29}$ Проучавајући наведене примере фалсификатора, могло би се закључити да већини новац није био једини мотив, већ да су били жељни и славе и признања, а неки су се, једноставно, забављали. Забележено је, уосталом, да је и Микеланђело „копирао цртеже старих мајстора тако савршено да се његове копије нису разликовале од оригинала, пошто је папир нијансирао и сушио у диму како би изгледао старо. Често је задржавао оригинале и уместо њих враћао своје

28 Ins, B. nav. delo, str. 87.

29 Dutton, D. Forgery and Plagiarism, 24. 03. 2016. http://www.denisdutton. com/forgery_and_plagiarism.htm 


\section{ДЕЈАНА ПРњАТ}

копије," ${ }^{30}$ мада су копије до 1500 године биле равноправне са оригиналима, ${ }^{31}$ уколико је слала исту поруку и могла да испуни исту религиозну или комеморативну функцију.

Иако је данас могуће радити велики број анализа артефаката за које се сумња да су оригинали, неке од њих су скупе, неке дуго трају, за неке су специјализовани само мали број стручњака, а неке неповратно оштећују део артефакта. Када би музеји и пристали на те анализе, приватни колекционари сигурно не би, поготово када се сетимо случаја у коме је власник једне Шагалове слике послао дело на проверу у Француску, а експерти утврдили да је у питању фалсификат и одмах је уништили ${ }^{32}$.

Искусни историчари уметности могу са великом сигурношћу да процене да ли је слика настала из атељеа неког уметника, али не увек и да ли је радио одређени сликар. Део проблема лежи и у некадашњем обичају да сликар који је имао атеље потписује радове својих ученика, било да је додао нешто, дорадио је или не. Исто тако, многи велики мајстори су сами правили копије својих слика, попут Ван Гога и Вазе са сунцокретима или Леонарда и Мона Лизе.

Зато ни аукцијска кућа као што је Сотби, ни поред процене својих експерата, не гарантује аутентичност за слике настале пре 1870. године. ${ }^{33}$ И поред тога, дешавали су се скандали, као када су 2000. године у исто време и Сотби и Кристи понудили Гогенову „Вазу са цвећем”, ${ }^{34}$ а она је настала 1896. године.

Стручњаци сматрају да ће у будућности фалсификаторима бити најпривлачнија дела савремених сликара, јер нису много проучавани и не морају да брину о материјалу који користе, као и артефакти афричке уметности 19. века попут маски или прародитељске фигуре, јер су једноставне

30 Vasari, G. (2006) The Lives of the most Excellent Painters, Sculptors, and Architects, New York; Modern Library cit. prem. Ins, B. (2008) Prevare $i$ falsifikati, Beograd : Mladinska knjiga, str. 44

31 Gopnika, B. In Praise of Art Forgeries, 16.03.2016. http://www.nytimes.co$\mathrm{m} / 2013 / 11 / 03 /$ opinion/sunday/in-praise-of-art-forgeries.html?_r=1

32 Fake $£ 100,000$ Marc Chagall painting 'to be destroyed', 02.02.2014, 12.03.2016., http://www.bbc.com/news/entertainment-arts-26000331

33 Swinger, K. B. "Sotheby's Sold Me a Fake" - Holding Auction Houses Accountable for Authenticating and Attributing Works of Fine Art, 28. 03. 2016., http://heinonline.org/HOL/LandingPage?handle=hein.journals/ cjla23\&div $=23 \&$ id $=\&$ page $=$

34 Bennet, W. Two versions of Gauguin work on sale at same time, 12.03.2004, 19.03.2016., http://www.telegraph.co.uk/news/worldnews/northamerica/usa/1456587/Two-versions-of-Gauguin-work-on-sale-at-same-time.html 
за копирање, рађене врло различитим стиловима, а цене за њих данас су врло високе. ${ }^{35}$

Сви наведени фалсификатори постали су познати, с тим што су неки од њих то желели, а неки не. Више њих је објавило књиге о фалсификовању, о некима је снимљен и филм. Интересантно је да су они којима је пажња медија пријала изјављивали да има још много њихових неоткривених радова на тржишту, али да никада неће открити о којим сликама се ради. Пошто се стиче утисак да су веома желели пажњу, могуће је да су намерно претеривали у броју својих неоткривених радова, али је сасвим извесно да их има, било да су нам фалсификатори познати или не.

Квалитетно урађеном фалсификату, сматра Лесинг, не може се оспорити естетски квалитет, већ је проблем што му недостаје оригиналност, што опонаша уметничко достигнуће из другог периода или другог уметника. ${ }^{36}$ Осим из естетских квалитета, материјална вредност артефаката зависи и од тога ко и када их је направио, па се прављењем фалсификата покушава уновчити туђа репутација. ${ }^{37}$ Нажалост, фалсификати не наносе само материјалну штету институцијама и приватним колекционарима који их поседују, већ утичу и на наше суштинско разумевање историје уметности.

\section{ЛИТЕРАТУРА:}

Gladwell, M. (2007) Blink, NY, Boston, London: Back Bay Books.

Gordić Petković, V. (2009) Formatiranje, Beograd: Službeni glasnik.

Indjić, T. (1986) Tržište dela likovnih umetnosti, Beograd: Zavod za proučavanje kulturnog razvitka.

Ins, B. (2008) Prevare i falsifikati, Beograd: Mladinska knjiga.

\section{Интернет извори:}

http://denisdutton.com

http://www.amazon.com

http://www.bbc.com

http://www.getty.edu

http://www.intenttodeceive.org

http://www.jstor.org/stable

http://www.nytimes.com

35 Dutton, D. Art Hoaxes, 22. 03. 2016. http://denisdutton.com/art_hoaxes.htm 36 Lessing, A. What Is Wrong with a Forgery?, 22. 03. 2016., http://www.jstor. org/stable/427668

37 Dutton, D. Art Hoaxes, 22. 03. 2016. http://denisdutton.com/art_hoaxes.htm 


\title{
ДЕЈАНА ПРњАТ
}

http://www.politika.rs

http://www.spiegel.de

http://www.telegraph.co.uk

http://www.wsj.com

\author{
Dejana Prnjat \\ Alfa University, Arts Academy - \\ Department of Arts and Media Production, Belgrade

\section{FORGERIES AND FORGERS ON THE} \\ FINE ARTS MARKET
}

\begin{abstract}
Many forgeries have been taken for originals for years, even centuries. With the advance of science and technology, it became possible to perform numerous analyses of artifacts whose authenticity is questioned. One would expect that those tests are run routinely, however, that is not the case. Analyses can be costly, may take a long time and some of them can even irrevocably damage the artifact tested. Therefore, even the most prestigious of museums worldwide have forgeries in their collections and the most renowned auction houses auction forgeries at the price of the originals, from time to time. Knowing that those prices sometimes reach millions of euros, it is clear that forgery has become a very lucrative business. Since verifying the authenticity of an artifact which was created in recent years is most difficult due to ready availability of the materials used, it can be anticipated that the art markets in the near future will be flooded with forgeries of modern art pieces.
\end{abstract}

Key words: forgery, forgers, fine arts market, museum collections, private collectors 